\title{
Los toros en Santiago de Chile durante el periodo colonial/
}

\section{Bullfighting at Santiago de Chile during the Colonial Period}

\author{
Escardiel González Estévez \\ ORCID iD: http://orcid.org/0000-0002-0963-4099 \\ Universidad de Sevilla \\ Olaya Sanfuentes Echeverría \\ ORCID iD: http://orcid.org/0000-0002-6951-1285 \\ Pontificia Universidad Católica de Chile
}

\begin{abstract}
A pesar de su inexistencia hoy en Chile, y de su olvido, los toros fueron, como en todo territorio dependiente del poder español, el centro del universo lúdico, con notorias implicaciones sociales. Aunque siguieron la trayectoria ibérica, evolucionando de lo ritual hacia el toreo espectáculo, existieron factores que particularizaron la tauromaquia en el contexto, como la prolongación del toreo caballeresco por su faceta de entrenamiento bélico con vistas a la frontera araucana.

Palabras clave: Toros; Tauromaquia; Fiesta; Santiago de Chile.

Despite the fact that in Chile there is no bullfighting and that people have forgotten it, bulls existed in this territory as in any other Spanish colony, with critical social implications. Although follow the Iberian trend, from ritual to a spectacle, some local factors made that bullfighting had special features in Chile, as is the case of the permanence of chivalrous bullfighting in the context of military training at the frontier with mapuche people.
\end{abstract}

KeYwords: Bulls; Bulfighting; Celebration; Santiago de Chile.

Copyright: (C) 2017 CSIC. Este es un artículo de acceso abierto distribuido bajo los términos de una licencia de uso y distribución Creative Commons Attribution (CC-by) España 3.0. 
En Chile apenas hubo toros. ${ }^{1}$ Esta es la errónea premisa con la que, tras un par de lacónicas referencias a lo sumo, se salva el particular en las obras generales dedicadas al estudio de la tauromaquia fuera de los límites ibéricos. ${ }^{2}$ Con Argentina, Paraguay y Uruguay, Chile integra la lista de los países «taurófobos» que han hecho del Cono Sur un lugar ajeno a la consideración de la fiesta. Resulta cuanto menos extraño que, siendo como fueron territorios dependientes del poder español, los toros no formaran parte de su universo lúdico. Sobre todo cuando sabemos que desde Italia a Filipinas existieron, y que en gran parte de América se siguen celebrando. Las causas de la desaparición son intrigantes, sobre todo por el contraste que se produce en el continente con otros contextos, pero ameritan un mayor estudio y más páginas donde exponerse. En las presentes nos limitaremos a enmendar el error y, más allá de lamentarnos de los «tan poco taurófilos» historiadores chilenos como Armando de María, nos ocuparemos de cubrir esta laguna historiográfica. No obstante, es de justicia reconocer que esta afirmación apesadumbrada del historiador mexicano es exceptuada por el reputado Pereira Salas, quien dedicó un capítulo en su célebre Juegos y alegrías coloniales, ${ }^{3}$ y por Isabel Cruz de Amenábar, quien también ha concedido espacio en su obra sobre la fiesta, ${ }^{4}$ al igual que, más recientemente, lo ha hecho Jaime Valenzuela. ${ }^{5}$ Pero cierto es que, más allá de noticias entreveradas en obras dedicadas al tema de la fiesta o al de la crónica de tal o cual ciudad, no encontramos un solo texto particularizado sobre la materia taurina en Chile.

Con la obligación de una mayor profundización en el horizonte, nos centraremos en esta ocasión en el desarrollo de la fiesta taurómaca en la ciudad de Santiago desde el siglo XVI hasta los primeros años del XIX, cuando se procede a su abolición. Adelantemos que no fue la capital el único lugar donde se celebró la fiesta y que, más allá de las latitudes

1 La idea — errónea- de que en Chile no hubo toros, se ha trasladado de igual forma hacia la historiografía. Efectivamente, no hay estudios historiográficos respecto a la práctica de la tauromaquia en Chile, sino solo menciones aisladas en obras dedicadas a otras temáticas. En este sentido, creemos que nuestro artículo puede ser un aporte frente al estado de la cuestión. De igual forma, creemos que puede servir de modelo para, a partir de una práctica concreta como es el caso de las corridas de toros, estudiar otros aspectos de la sociedad que se ven reflejados y relevados elocuentemente.

2 Cossío (1951, VI, 367-369) solo le dedica unos párrafos. López Izquierdo, 1992, 328-330. En la obra de Molinié-Bertrand, Duviols y Guillaume-Alonso (1999) no encontramos artículos dedicados a Chile, pero sí a Argentina. Tampoco figuran en el clásico de Bennassar (1993), o el más reciente de Maudet (2010), a pesar de estar centrado, en buena medida, en América.

3 Pereira Salas, 1947, 63-107.

4 Cruz de Amenábar, 1995.

5 Valenzuela, 2005 y 2014. 
septentrionales, ${ }^{6}$ como cabe lógicamente suponer, también se practicaron en puntos más meridionales como Valdivia. ${ }^{7}$ Nuestra aproximación ofrece una evolución diacrónica de la fiesta capitalina desde sus inicios en torno a 1555 hasta el cierre del siglo XVIII, focalizando la atención en aspectos que hemos considerado de relevancia: la casuística de la fiesta; su imbricación con el calendario festivo religioso y el esfuerzo por mantenerla por encima de los cambios a los que las inclemencias meteorológicas avocaron; las tensiones que suscitó entre las autoridades eclesiásticas y civiles; su condición de espejo de lo caballeresco; o su transformación en espectáculo a lo largo del siglo XVIII. Al alimón, para utilizar una expresión taurina, nos complace presentar este trabajo con el que dejar de ignorar que en Chile hubo toros. Los hubo, y con más asiduidad y relevancia de lo que generalmente se cree.

\section{La metamorfosis de fiesta de toros ritual a moderno espectáculo taurino}

El criterio para establecer las diferentes fases de la tauromaquia se asienta sobre la naturaleza de la fiesta, que experimenta un viraje de lo festivo-ritual al espectáculo en torno a los comedios del siglo XVIII. Nos alejamos de este modo de la organización bipolar toreo ecuestre / toreo pedestre que vienen señalando los estudios al respecto desde García-Baquero a Guillaume-Alonso, ${ }^{8}$ por entender que, aunque ciertamente existe un predominio de una forma sobre otra en épocas sucesivas, ambas se solapan y no dejan interactuar en todo el proceso hasta el triunfo indiscutible del toreo a pie en el siglo XIX. Así, durante la época colonial se distinguen en Chile dos periodos: el primero, que abarca desde los años iniciales de la conquista española hasta comedios del siglo XVIII, al que denominamos toreo festivo-ritual; y el segundo, desde entonces hasta la abolición en 1823, que corresponde al toreo-espectáculo.

6 Incluso en lugares tan inhóspitos como el altiplano andino, sabemos de la existencia de esta fiesta en las plazas públicas de pequeños poblados, como la pintura mural de algunas iglesias atestigua.

7 Guarda, 1984, 241-262. La efeméride contó con sus correspondientes toros, los más australes registrados documentalmente hasta la fecha, aunque fueran «bastarda producción de las montañas».

8 García-Baquero, 2008. Guillaume-Alonso, 1994. 


\section{El toreo festivo-ritual (siglos XVI-XVIII)}

Los toros tuvieron en esta etapa un carácter eminentemente caballeresco. Como sucedía en la metrópoli, estuvieron inseparablemente unidos a los habituales juegos ecuestres: sortija, estafermo, pero especialmente las cañas, que llegaron a rivalizar en protagonismo hasta mediados del siglo XVII, para desaparecer a partir de entonces. Pero más que allí o que en otros escenarios americanos, el toreo de a caballo fue una actividad más necesaria y destacada por una circunstancia que hizo de estas tierras australes uno de los puntos candentes de la resistencia indígena: las guerras contra los mapuches. De este modo, la tendencia connatural hacia la vertiente ecuestre de la tauromaquia en esta etapa se vio incrementada por el recio y prolongado conflicto araucano, haciendo del enfrentamiento con el toro desde el caballo un ejercicio ecuestre útil, como recogen las actas del cabildo de Santiago: «que no cese el arte militar [el toreo ecuestre], pues tan necesario es que se ejerza en esta tierra por estar de guerra, como está». ${ }^{9} \mathrm{El}$ patronazgo del santo ecuestre y bélico por excelencia sobre el territorio y el trasvase al patronímico de la capital no son casuales. Con Santiago se trabará una relación crucial (aunque no exenta de problemas) en el ámbito festivo-religioso, dentro del cual los toros llegaron a constituir el punto álgido.

En Santiago existieron corridas ordinarias, vinculadas al calendario litúrgico-festivo, y corridas extraordinarias, motivadas por sucesos de índole fundamentalmente civil y de carácter más exógeno que concerniente a sucesos internos, aunque también entre estas existieron algunas de tono particular.

Las primeras se celebraron en torno a dos fechas principales: la del patrono Santiago, el 25 de julio, y la de la Asunción, el 15 de agosto, ya que la de San Juan, pronto desaparece de la documentación no alcanzando

9 Cabildo de Santiago, 31 de agosto de 1582, Archivo Nacional Histórico de Chile (en adelante ANH Chile), Actas del Cabildo de Santiago (en adelante ACS), 2. ${ }^{\circ}$ rollo LCH 95. [La consulta de estas actas solo se permite actualmente a través de microfilm, por lo que las citas se consignarán según la ordenación asignada por el archivo en tal soporte, como arriba se ha referido. No obstante, las actas entre 1541 y 1810 han sido publicadas en varios volúmenes desde fines del siglo XIX. Remitimos al lector interesado en su consulta a tales volúmenes, con una mayor accesibilidad. Por ejemplo, para este acta de 1582 a la que nos referimos en la presente nota: Medina, 1899, 43. Un listado de los primeros once tomos que recogen las actas del cabildo — junto con otras fuentes de la historia de Chile_- especificando los años comprendidos en cada volumen se puede consultar en Chiappa, 1905; no así para los tomos sucesivos]. En Lima se tiene la misma preocupación y un decenio antes el cabildo de la ciudad justifica los toros «para que los de a caballo se exerciten en la caballería que se ba perdiendo por el poco exerçicio que ay en ello», citado en Molinié-Bertrand, Duviols y Guillaume-Alonso, 1999, 162. 
a traspasar el siglo XVI. ${ }^{10}$ Estas fechas que en España marcaban los hitos festivos del periodo estival resultaban especialmente inapropiadas para el invierno austral de la capital chilena. Fue esta circunstancia la que acarreó complicaciones constantes a causa del necesario traslado de la fiesta, especialmente los años donde las inclemencias meteorológicas fueron más adversas. Así, en 1654, el cabildo acordaba retrasarla hasta fines de octubre porque aun «queriéndose hacer, no se han de correr y por el invierno no se han corrido». ${ }^{11}$ Aunque durante el siglo XVI el 25 de julio se mantuvo, estoicamente hemos de pensar, en la siguiente centuria la fiesta de los toros dedicada al apóstol va postergándose, uniéndose en ocasiones a celebraciones puntuales, y las más de las veces a la festividad de la Asunción.

A pesar de los esfuerzos por ajustarse a la fecha y mantener los toros del patrón «como era uso y costumbre», lo cierto es que para 1666, «como la festividad de los toros del señor Santiago se había dejado ya al presente», ${ }^{12}$ se intercambiaron por otra festividad mariana de gran impulso por aquellos años y que se convertiría en una de las referencias devocionales de la monarquía hispánica y su imperio: la «Limpia Concepción». ${ }^{13}$ Por cierto, mucho más apropiada meteorológicamente: en la agradable primavera final chilena, el 8 de diciembre. No obstante, el cabildo continuó esforzándose por mantener un aspecto tan relevante para su identidad como la celebración de las fiestas taurinas del patrono y el 9 de noviembre de 1711 el cabildo destinaba quinientos pesos a los toros de Santiago y ordenaba que «sean todos los años». Pero lo cierto es que no volveremos a encontrar más noticias taurinas al respecto, y sí problemas de financiación para mantener la celebración.

Quizá esta inconveniencia del 25 de julio austral para correr toros fuera una de las causas que motivó la extinción de la fiesta taurómaca hacia el segundo cuarto del siglo XVIII en su perfil de fiesta ordinaria en relación con el calendario litúrgico, y quizá también lo fuese para el escaso éxito de

10 De hecho, solo hemos podido encontrar la advocación joánica en una referencia de 1575 cuando se habla de estas tres datas. Cabildo de Santiago, 15 de julio de 1575 , ANH Chile, ACS, $1 .^{\circ}$ rollo LCH 94. Las actas referencian que en 1582 «se corran toros el día de Nuestra Señora de Septiembre»,

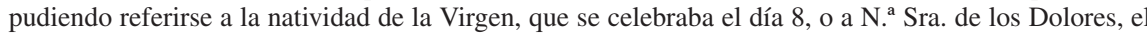
15, pero es, como la data joánica, marginal. Cabildo de Santiago, 31 de agosto de 1582, ANH Chile, ACS, 2. ${ }^{\circ}$ rollo LCH 95.

11 Cabildo de Santiago, 11 de septiembre de 1654, AHN Chile, ACS, 9. ${ }^{\circ}$ rollo LCH 116

12 Cabildo de Santiago, 5 de octubre de 1666, AHN Chile, ACS, 11. . rollo LCH 125.

13 Campos y Fernández de Sevilla, 2005. El 8 de diciembre fue declarado fiesta de guardar en todos los reinos de su majestad católica desde 1644, cuando fue adoptada como patrona y protectora por Felipe IV, uno de los muchos monarcas españoles que contribuyeron a esta piedad, la cual culmina con la proclamación dogmática en 1854 . 
la festividad en líneas generales, borrada en la actualidad de la memoria de la ciudad a pesar, paradójicamente, de su nombre. ${ }^{14}$ Pero los toros se siguieron corriendo, y lo siguieron haciendo no solo motivados por hitos excepcionales sino en su faceta de entretenimiento ordinario (permanente, digamos) de los santiaguinos, aunque convertidos ya en espectáculo. Esto se produce muy pocos años después de que dejemos de encontrar referencias a los toros jacobeos, pues en $1732^{15}$ ya se consigna la primera corrida fuera de los límites de la plaza mayor, que había sido el espacio taurino en virtud de su estatus de punto neurálgico de la fiesta urbana.

Esto por lo que concierne a la fiesta taurina ordinaria o frecuente, pero los toros también constituyeron parte ineludible, por no decir principal o única, de aquellos hitos históricos que moldearon el devenir de la vida colonial santiaguina. Las corridas extraordinarias venían motivadas por sucesos de índole civil y, principalmente, no acaecidos dentro de las fronteras del territorio, ni tan siquiera del continente; como los éxitos militares del ejército español, que en Santiago fueron festejados en el caso de los conflictos catalanes. ${ }^{16}$ Se trataba de celebrar el afianzamiento del poder, que era también el trasfondo de las celebraciones más repetidas en todo el imperio, aquellas relativas a la sucesión en la corona: juras y, en menor medida, natalicios. Santiago no era México ni la Ciudad de los Reyes, pero no les iba a la zaga. La urbe no escatimó con las juras reales desde Carlos II a Carlos IV, incluso celebró la coronación de Fernando III de Habsburgo en 1638, y natalicios: el del malogrado Felipe Próspero y el de Carlos José en 1663.

En paralelo se celebrará también la posesión de otro cetro, el del poder de la gobernación de Chile, aunque en bastantes casos con no pocos aprietos económicos que obligarán a retrasar, cuando no a eliminar, los agasajos a pesar de la probada intención de realizarlos. Las entradas de gobernadores se celebraron fundamentalmente en el siglo XVII y raramente en el XVIII,

14 También se ha argumentado que la fiesta y la devoción a Santiago se perdieron en la capital por la relación intrínseca que había entre este santo y la monarquía hispánica. Con la llegada de la independencia se fueron eliminando todos los símbolos de la monarquía y la figura del apóstol español fue una de las primeras en desaparecer. El libertador Bernardo O’Higgins, por su parte, inauguró una devoción institucional a la Virgen del Carmen, la que ocupa desde entonces el lugar del apóstol en las mentes de los santiaguinos. Cada 16 de julio los habitantes de la capital y de todo el territorio de Chile en general le rinde culto a la Virgen del Carmen, «reina y patrona de Chile». 1947,71 .

15 ANH Chile, Real Audiencia, 2697, pieza 1, 15r-29v. Citado también por Pereira Salas,

16 Cabildo de Santiago, 9 de noviembre de 1711, AHN Chile, ACS, $16^{\circ}$ rollo LCH 130. Se festejaron la victoria en la guerra de Cataluña en 1653 y la toma de Gerona en 1711. Alemparte Robles, $1940,303$. 
aunque la del presidente Joaquín del Pino, el penúltimo gobernante colonial, fue célebre. Así, F. Meneses en 1664, o el marqués de Navamorcuente cuatro años después, fueron lisonjeados con toros; otros tuvieron menos suerte, como Acuña y Cabrera, ${ }^{17}$ las arcas se encontraban poco llenas entonces para tales dispensas. En otros momentos más boyantes recibieron el agasajo de los toros personajes de otro rango como el presidente de la Audiencia J. Henríquez, ${ }^{18}$ o incluso la esposa del gobernador Bravo de Saravia, por cierto, la primera ocasión en que se registran toros para un suceso extraordinario, corría $1568 .{ }^{19}$ La fiesta por la canonización de san Francisco Solano en 1633 constituye el único evento de tono religioso. ${ }^{20}$

Pero también hubo, entre los festejos extraordinarios, otros de carácter particular o privado por parte de la «gente más principal o poderosa». El motivo atendía, según Alonso de Ovalle, a dos eventos concretos: bautismos y bodas. ${ }^{21} \mathrm{El}$ cronista jesuita lo relata con respecto a Santiago en el segundo tercio del siglo XVII, aunque quizá la práctica se realizase con anterioridad, y raramente traspasada esa centuria. Tampoco existen referencias similares para otras latitudes del territorio chileno, ni del mundo hispánico. La emulación de la monarquía parece exceder los límites en este caso, pues correr toros para natalicios y matrimonios había sido prerrogativa real desde el alto medievo. Solo el grado de doctor o la profesión monacal habían motivado toros con este carácter «particular» y no monárquico en la península. Pero la cúspide social de Santiago del Nuevo Extremo fue, desde su fundación, una nobleza caballeresca altamente militarizada por las vicisitudes bélicas, díscola y alejada del trono, sin embarazo en asumir este tipo de celebración reservada a los monarcas.

\section{De ejercicio militar a espectáculo barroco (siglo XVIII)}

A partir del segundo tercio del siglo XVIII se opera, siguiendo la evolución de la metrópoli, la transformación del festejo patronal taurino en espectáculo despojado ya de su aspecto ritual. ${ }^{22} \mathrm{El}$ objetivo pasa a ser ahora económico, una manera de financiar determinados proyectos, bien en clave de obras públicas como la construcción de un puente, la expansión o

17 Cruz de Amenábar, 1995, 282-283.

18 Cabildo de Santiago, 7 de septiembre de 1672, AHN Chile, ACS, 12. ${ }^{\circ}$ rollo, LCH 126.

19 Pereira Salas, 1947, 102, nota 3.

20 Ibidem, 21. Medina, 1952, 247-248.

21 Ovalle, 1974 [1646], 87.

22 Romero de Solís, 1995. García-Baquero, 2008, 121-123. 
adecentamiento de la alameda, la conducción de agua a la plaza mayor o la refacción de las casas capitulares; o bien con carácter benéfico: sustento para reos o niños expósitos. El organismo administrador será el cabildo, sacando a pública subasta los derechos de explotación del espectáculo por espacios de tiempo de entre cinco y diez años con rentas sustanciosas de mil pesos anuales, más un ciento de estos por corrida. Además, existe la obligación de reservar determinados sitios, los mejores, para los estamentos gubernamentales de la ciudad que, siguiendo la costumbre de los festejos en la plaza mayor, podían acudir gratuitamente con sus familias y esclavos. Esta prerrogativa se convirtió, junto a otras, en argumento quejoso para justificar la imposibilidad del pago de la renta contraída en los contratos por parte del empresario, lo cual generó largos pleitos que constituyen una de las tipologías documentales más abundantes y ricas para los estudios taurinos, aunque, no podemos negarlo, farragosas. Conoceremos a través de ello precios, tipos y nombres de participantes, objetos necesarios para el desarrollo de la fiesta o el sesgo del público. En definitiva, la necesaria reglamentación del festejo a que conllevó su carácter de espectáculo de pago, se tradujo en una codificación, pero ¿qué mantuvo de las fiestas extraordinarias como las juras, también reglamentadas?, ¿diferían mucho de lo desarrollado en la metrópoli o en otros contextos?

\section{Una tauromaquia austral: los rasgos de la fiesta en Santiago de Chile}

Con los escasos datos obtenidos del periodo relativo a la tauromaquia festivo-ritual, desarrollada desde el siglo XVI hasta el primer tercio del XVIII, intentaremos estructurar un correlato en torno a diversos aspectos en cotejo con aquellos otros que se producen en el siguiente periodo: el toreo-espectáculo, que se desarrolla desde el segundo tercio de la centuria. Abordaremos por un lado en la lidia y sus componentes: el animal y los toreadores, su desarrollo, sus suertes o tipos de tratos con el toro, el espacio; y por otro, el público y los organizadores.

\section{El toro}

Todavía sigue resultando un misterio cuándo llegaron algunas especies de toro bravo a América, es más, se desconoce si realmente este arribo llegó a producirse y es que a la problemática del traslado de cualquier 


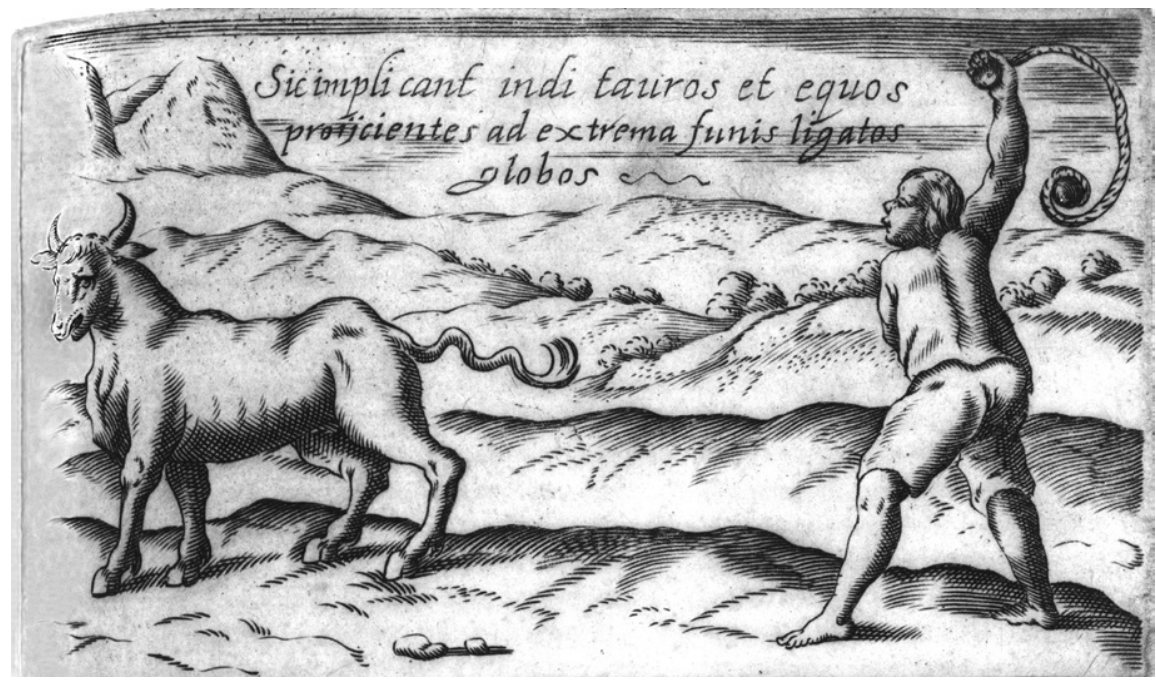

FIGURA 1. Grabado con escena de caza taurina por un indígena contenido en la Histórica Relación del Reino de Chile de Alonso de Ovalle; las matrices, anónimas, fueron realizadas en Italia, donde se publicó la obra del jesuita (Roma, 1646). La traducción del texto en latín es: «Así alancean los indios a los toros y a los caballos, lanzándoles [a las patas] unos bolos atados al extremo de una cuerda».

animal de dimensiones considerables se sumaban las características de fiereza y peligrosidad del bruto. ${ }^{23}$ Barros Arana consigna la fecha de 1548 para la presencia de ganado vacuno en tierras chilenas ${ }^{24}$ y recordemos que solo doce años después ya se están corriendo toros.

La postura del indígena ante el novedoso animal pasó del temor y extrañeza de los primeros momentos ${ }^{25}$ a un dominio por medios propios, que en Chile se dio a través del uso de boleadoras para su caza. Así lo refleja la imagen inserta en la obra del jesuita Alonso de Ovalle, ${ }^{26}$ aludiendo a una realidad existente al menos desde comienzos del siglo XVII (figura 1)

23 Pereira Salas, 1947, 63. López Izquierdo, 1992, 18-26.

24 Barros Arana, 2000, 268: «Según se lee en un título de encomienda dada algunos años más tarde a Francisco de Alvarado, este trajo en 1548, diez vacas y diez toros, que cuidados esmeradamente, se propagaron bien y fueron el origen de las considerables masas de ganado que medio siglo después poblaban todos los campos de Chile». Desde Perú, se presupone.

25 El Inca Garcilaso, ante la visión de unos bueyes de arado, cuenta cómo en su niñez «un ejército de indios que de todas partes iban a lo mismo, atónitos y asombrados de una cosa tan monstruosa y nueva para ellos y para mí... y creo que los solemnes triunfos de grandes de Roma no fueron más mirados que los bueyes de aquel día». Garcilaso de la Vega, 1976 [1609], II, 243-244.

26 Ovalle, 1974 [1646], 46. 
y que ha sido difundida como rasgo del gaucho argentino, aunque este lo emplea desde el caballo. La lidia mantenía una íntima conexión con la caza de toros cimarrones, como Argote de Molina ya había indicado para 1582 a tenor de las islas antillanas, ${ }^{27} \mathrm{y}$ constituía parte capital en la cinegética del país andino, como Claudio Gay pone de manifiesto en su Atlas (figura 2). Hacia 1744, el Sínodo de Concepción advierte en su Constitución V que el exceso de vacas en «tierra de los indios» iba en detrimento de los diezmos, ${ }^{28}$ evidenciando una preponderancia en la cría y trato del ganado vacuno por parte de los indígenas sobre españoles y criollos. En otras zonas de América, especialmente en el Collao, tan próximo a Chile, el sincretismo del toro con elementos culturales prehispánicos diversos es patente; se ve ya desde el siglo XVI en algunos keros, en los toritos cerámicos de Pucará, o en la impactante Yawar fiesta, donde se cosen las garras del cóndor al toro para ser toreado. ${ }^{29}$

Hemos de suponer que en el siglo XVI sería difícil encontrar especímenes que cumpliesen los requisitos que se le demandaban al toro de lidia, y poco lógico malgastar ejemplares con una cabaña tan corta. Dejando a un lado la incógnita de un traslado de toro bravo ibérico y pasados los tiempos de limitaciones de carácter cárnico, podemos suponer la existencia de animales más embravecidos por cruces genéticos. Más adelante, la propagación asilvestrada en parajes alejados e inaccesibles desembocó en una feroz y feraz existencia de ganado vacuno «atacando [...] un gran número de caballos y no pocos infelices vaqueros», en palabras del abate Molina. ${ }^{30}$

\section{Los lidiadores}

El perfil de los actores de la lidia fue, en la primera etapa, aristocrático o al menos relativo al estamento dirigente, de la misma manera que por entonces ocurría en la península. Los caballeros, como etimológicamente indica la palabra, fueron los que, al estar en posesión del caballo, podían participar. Esta naturaleza caballeresca del toreo de esos siglos fue en Chile más acusada, atendiendo a la situación conflictiva en la frontera meridional.

27 Citado por López Izquierdo, 1992, 159.

28 Primer Sínodo Diocesana [1744], 1867, 48-49.

29 Castillo Martos, 2003. Para la Yawar fiesta véase Molinié, 2003.

30 Molina, 1788, 374. 


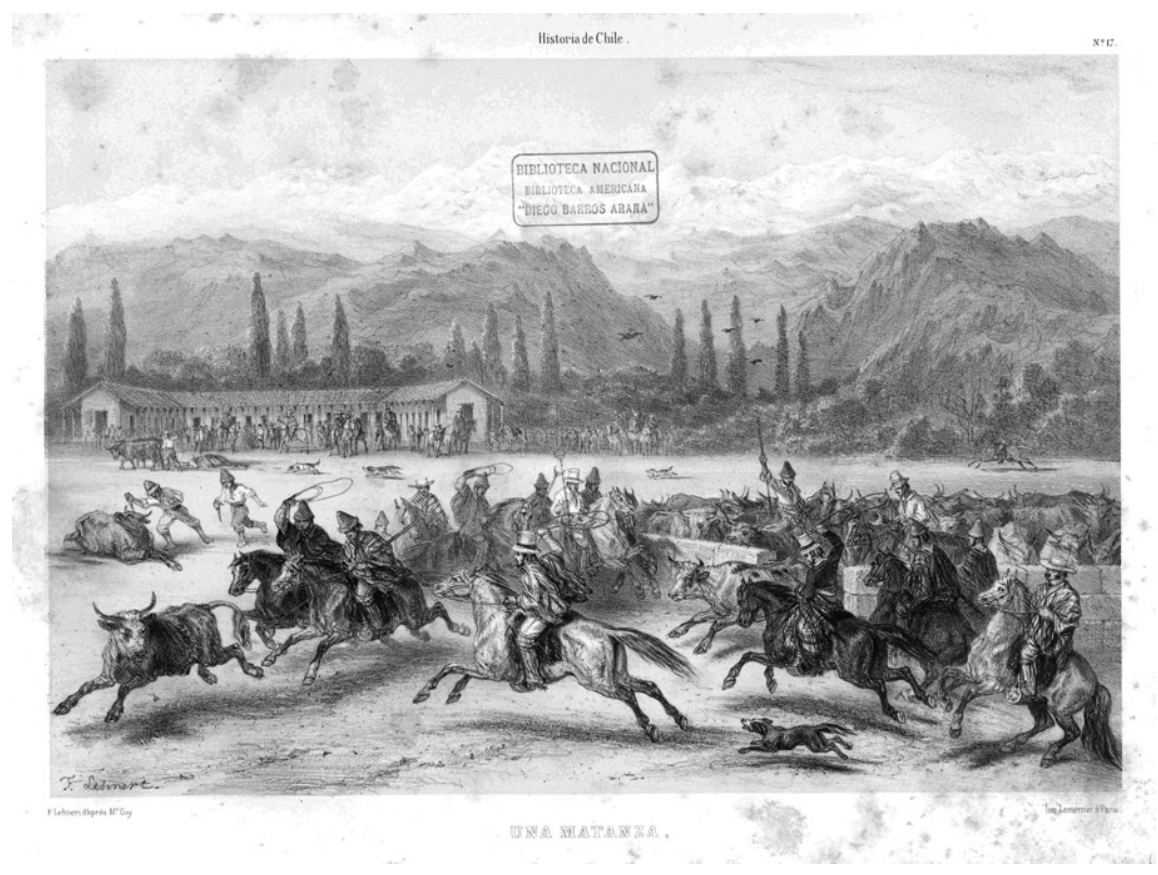

FIGURA 2. Grabado «Una Matanza», n 17 del Atlas de la historia física y política de Chile de Claudio Gay (París, Imprenta de E. Thunot, 1854); los dibujos son del propio Gay, los grabados de F. Lehnert.

La tauromaquia caballeresca mantuvo aquí por un prolongado tiempo la razón de ser que la gestó: un entrenamiento para la guerra, mientras que en España ya se acusaba una decadencia desde comienzos del siglo XVII con la negativa de la nobleza a intervenir en los festejos. ${ }^{31}$ Esta particularidad parece la causa de la intervención de «toreadores de a caballo» hasta el mismo siglo XIX ${ }^{32}$ e incluso dentro de la coyuntura del toreo-espectáculo, vinculado por norma al toreo a pie.

En un punto septentrional como Pachama, perteneciente a la doctrina de Codpa, en la región precordillerana de Arica, ${ }^{33}$ encontramos una sugerente pintura mural en los pies del templo donde puede apreciarse, junto a otras temáticas profanas y costumbristas, una escena de toreo ecuestre en

31 Guillaume-Alonso, 1994, 251.

32 Johnston, 1917, 137.

33 Chacama Rodríguez, 2009, 23-24. 
un paisaje urbano, interaccionado con un dragón (figura 3). Más allá de elucubraciones acerca del parangón toro-dragón como símbolos del mal (y otras más que pudieran hacerse desde la iconografía), nos interesa aquí la asimilación de una escena taurómaca en el imaginario de una población del actual norte de Chile, aunque históricamente conectada a Potosí, una ciudad con amplia tradición taurina como el cronista Arzáns de Ursúa, entre otros, se encargó de reflejar. ${ }^{34}$ Es la única imagen de un torero de a caballo que tenemos para Chile durante la tauromaquia colonial, y una de las pocas de América. El caballero, tocado con sombrero, vuelve el rostro hacia un enorme astado, sin duda desproporcionado, pero ¿por una impericia con las leyes de la perspectiva o con la intención de sobredimensionar las facultades del animal? Acaba de hacer un quiebro y, como revela el instrumento en su mano, de hundir un rejón en la cerviz del toro. Este, enfurecido, embiste las ancas del caballo que no por naif, deja de transmitir menor sensación de dinamismo. Puede afirmarse, entonces, que el toreo ecuestre formaba parte del imaginario de este territorio al menos hacia fines del siglo XVIII, momento en el que puede datarse la pintura. Lo seguirá haciendo en la siguiente centuria, como testimonia un documento alusivo a una fiesta de toros celebrada en 1845 en la plaza de Belén, una doctrina de indios a cuatro kilómetros de Pachama. ${ }^{35}$

Entendemos que el predominio del caballo en la lidia no fue en estos años excluyente de un toreo a pie que pudo haber tenido muchos matices, desde la indiscutible participación de los lacayos dentro de la tauromaquia caballeresca, hasta un no documentado toreo popular y espontáneo a socapa de la primera. Sí se confirman para Chile tratos con el toro en contextos agrarios, con una práctica tan americana como la monta del animal..$^{36}$ Esta tauromaquia, de raigambre medieval, nunca dejó de practicarse en España ni en el momento de mayor auge de lo caballeresco, dándose especialmente en las tareas previas de conducción y encierro del animal, así como en las capeas de raíz agraria o en el «laboratorio» de la encrucijada de ambas que suponía el matadero. Los protagonistas de este toreo lúdico y tumultuoso fueron, lógico es, plebeyos, planteando una dicotomía frente al caballero que tiene en la tauromaquia y su evolución un fiel reflejo de la sociedad coetánea.

34 Arzáns de Orsúa y Vela, 1970, 51-52, por citar un ejemplo, ya que las referencias son abundantes.

35 Acuerdo (Sobre que Francisco Cuéllar sea mayordomo de las cofradías de Belén en lugar de Blas Benavides), 21 de enero de 1845 - 9 de julio de 1846, Archivo Arzobispal de Arequipa, Vicaría, Arica, Belén, Mayordomía de las Cofradías de Belén, 66, s/f.

36 Olivares, 1864 [1758], 75. 


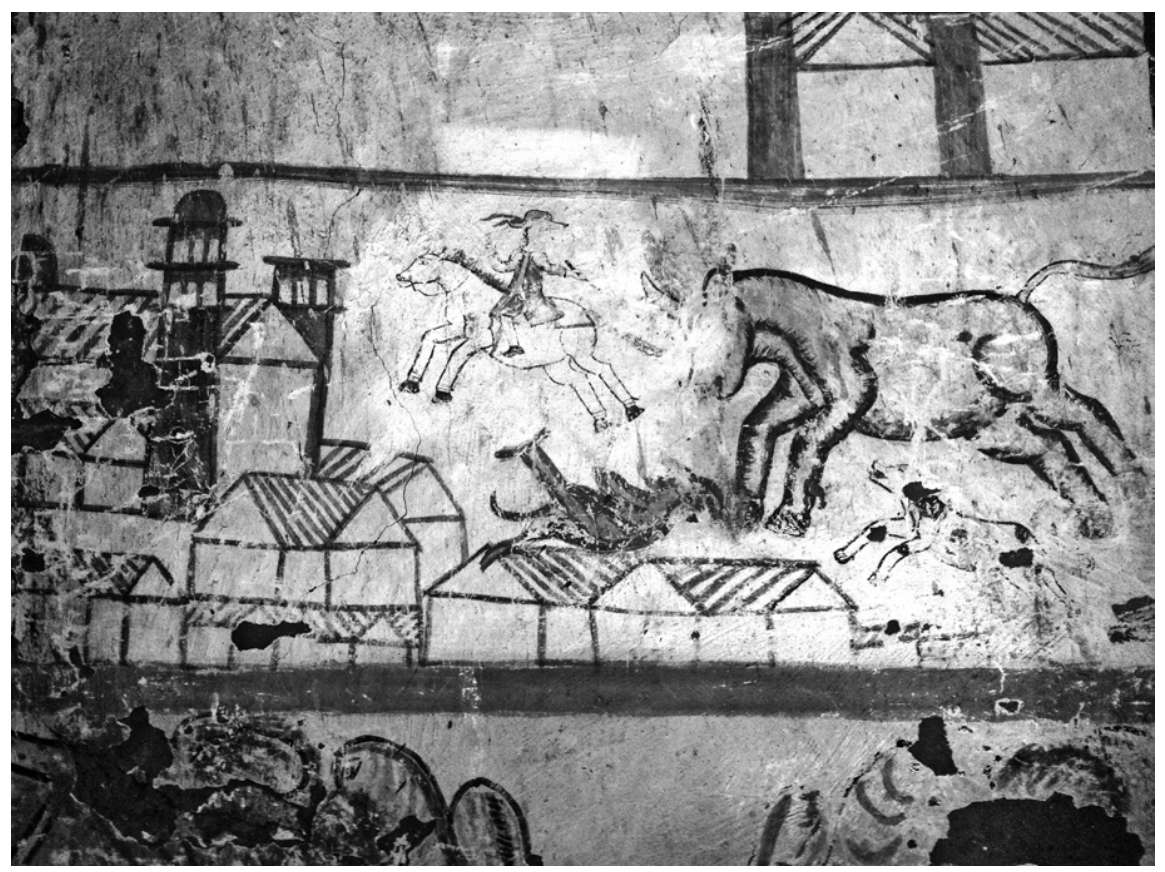

Figura 3. Pintura mural anónima con escena de un caballero corriendo un toro, segunda mitad del siglo XVIII. Iglesia de San Andrés de Pachama (muro interior, en el lado de la epístola flanqueando la puerta de ingreso), Precordillera, Región de Arica y Parinacota.

Claro que decir plebeyo en el Santiago colonial esconde una mayor complejidad, al menos heterogeneidad, que en la península. Entendamos el término en negativo, como un gran cajón donde se acoge a todos los individuos que no integraban la reducida élite dirigente. Más allá de peninsulares de baja estofa primero y de criollos después, ¿qué papel correspondió a indígenas, mestizos o negros? Desafortunadamente no contamos con datos como en el virreinato peruano, donde Fernando Iwasaki ha subrayado la temprana participación de indígenas y su protagonismo en determinados lances, también de negros. ${ }^{37}$ Bernal Díaz del Castillo lo corrobora respecto al virreinato de Nueva España cuando dice que los indios «y aun en algunos

37 Iwasaki Cauti, 1992. En 1572, el arzobispo Loayza, expresa: «Más peligro e ynconveniente ay en esta tierra por causa de que los yndios que en ese reyno, porque, como los toros se corren en fiestas y en tales días los yndios suelen beber demasiado, demás de ser gente torpe, hieren y matan algunos, $\mathrm{y}$, aunque se ha preveydo que no salgan yndios a la plaza, no se puede guardar enteramente». Cit. en Ibidem, 313-314. 
pueblos juegan cañas y corren toros [...] y hay muchos que aguardan los toros y aunque sean bravos».$^{38}$ Para el ámbito neogranadino el cronista Fernández de Oviedo también refuerza la idea subrayando la celebridad de los indios coyaima y notagaima, así como de los negros, en las fiestas taurinas. ${ }^{39}$ Sus intervenciones se asimilaron a un toreo pedestre y, en no pocos casos, a la vertiente cómica y burlesca de este, aunque, cabe decir, no solo. ${ }^{40}$ Decididamente puede hablarse de la apertura de la tauromaquia a los no españoles desde muy temprano y de forma dilatada, y ello es tremendamente interesante desde el punto de vista de que supone una forma de integración cultural. ${ }^{41}$

¿Hemos de entender que, habida cuenta de lo extendido de la práctica, en Chile sucediese lo mismo? El testimonio al respecto es tardío: en 1760 el arzobispo Alday hace una recomendación en contra de las «gentes de castas que aquí suelen dedicarse a los toros». ${ }^{42}$ Ello, además de evidenciar la participación de las castas, deja entrever otro aspecto: la profesionalización del arte del toreo, uno de los puntales de la evolución al toreo dieciochesco. En España la primera noticia respecto al pago a un torero es la que aparece en Sevilla en 1733. Miguel Canelo cobra 2.100 reales, el doble de lo que podía ganar al año un empleado del matadero. ${ }^{43}$ Sabemos que en México se ofrecen 100 pesos como premio a la mejor lanzada. ${ }^{44}$

El ascenso social a través del toreo, muchas veces vertiginoso y por ello con tintes de milagro, es incuestionable y en América al factor económico se suma el étnico. El parangón con el fútbol en la actualidad es difícil de soslayar, aunque en una época con una ausencia de movilidad social endémica, aun resulta más asombroso. Todos, desde el español más encopetado hasta el mestizo más empobrecido, pueden participar en la tauromaquia,

38 López Izquierdo, 1994, 27. Añade el cronista las fechas: Corpus Christi, San Juan o Santiago, y «nuestra señora de Agosto». Nótese las coincidencias con los primeros cabildos santiaguinos, confirmándose como fechas taurinas.

39 Rodríguez, 1999, 166. Véase también para el contexto quiteño Alfonso Mola y Martínez Shaw, 2003.

40 Iwasaki Cauti, 1992, 318. En una relación de 1659 se indica como «salieron dos indios a garrochear a los toros» (cit. en Ibidem, 320). Se trata, por tanto, de una suerte ecuestre. Recordemos que el capeo, lance donde se utiliza la capa o capote desde el caballo, es de origen peruano.

41 Fournier, 1999, 188. El autor cita un proceso del tribunal del Santo Oficio de la Inquisición de Celaya a comienzos del siglo XVII, donde mestizos e indios estaban acusados de haber hecho un pacto con el diablo para «ser buenos caballeros y buenos toreros». Significativo testimonio que demuestra el interés de un tema sobre el que seguir ahondando.

42 Pereira Salas, 1947, 74, nota 24.

43 García-Baquero, 2008, 40-41.

44 Fournier, 1999, 188 
con un factor de competencia de innegable atractivo para el concepto de igualdad en una sociedad extremadamente clasista. Negros alanceando toros a caballo, reos desterrados, indios y castas con alta e importante participación, primero, y profesionales, después; todos con la posibilidad de competir en torno a los conceptos de destreza y valor con el alto estamento, y ascender. Ascender simbólicamente y, en muchos casos, de forma real. La litografía de un arrogante torero negro de a caballo en Lima, fechable en 1855 , refleja soberbiamente esta realidad (figura 4).

En Chile el británico John Byron recoge que en 1744 (solo una década después que en España) «algunos [sin especificar carácter étnico] se dedican por oficio», ${ }^{45}$ no mostrando empacho en afirmar que las fiestas son mejores que en Lisboa. Sin embargo, los salarios registrados están lejos,

FIgURA 4. Litografía a color anónima con un capeador negro a caballo, Lima, 1855.

En Recuerdos de Lima.

Álbum. Tipos, trajes y costumbres, de A. A.

Bonnaffé, Lima, 1857.

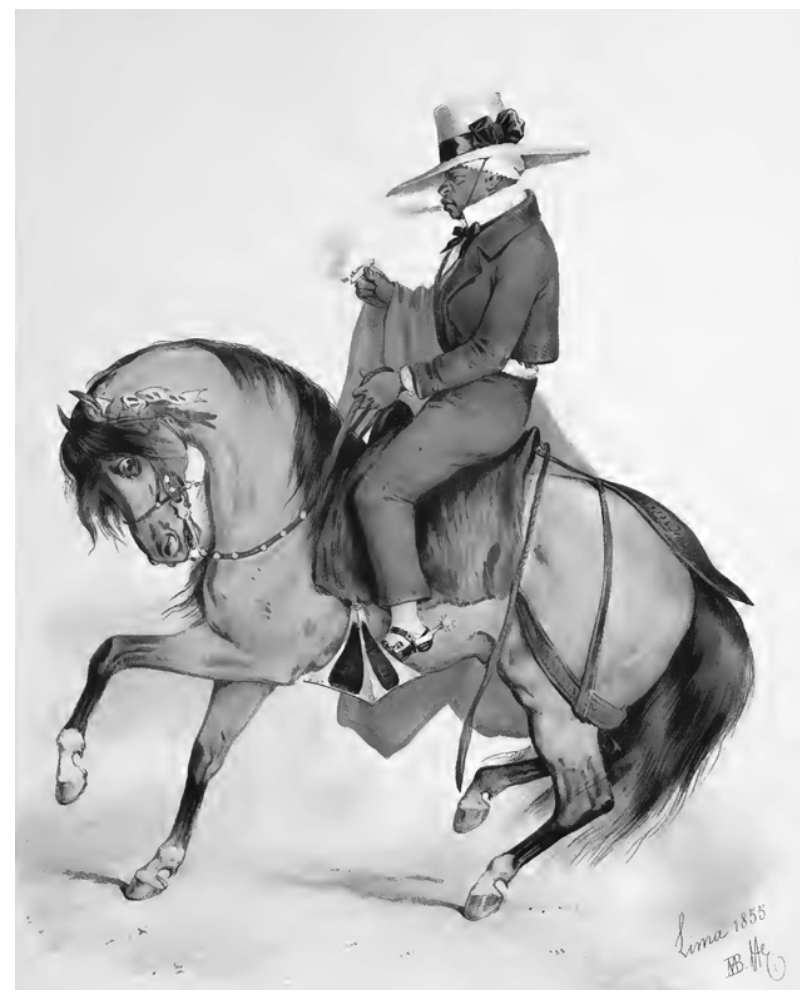

45 Byron, 1901, 139. 
muy lejos, de estas cifras: en 1764 seis pesos ${ }^{46}$ en 1773 , cinco pesos,${ }^{47}$ lo pagado a ocho toreros, más la cuadrilla y los participantes en la mojiganga, por los cinco días de toros que se ofrecieron al nuevo presidente Joaquín del Pino (1799) ascendía a 180 pesos, pero no se desglosan. ${ }^{48}$ Puntualicemos que los toreadores de a caballo también recibieron una dotación económica, aunque sin carácter de estipendio, o bien alguna prerrogativa. Así, en 1784 el capitán Pedro Valenzuela solicita que como «siempre que la magnificencia de Su Majestad ha querido premiar estas acciones con algún empleo», se le exonerase de cuatrocientos pesos de censo que había de pagar sobre la chácara en la villa de Santa Cruz de Triana por salir a torear en la jura de Fernando VI, reconociendo, no obstante, que «aunque exponer mi vida al riesgo de perderla es propio y debido obsequio de mi lealtad». ${ }^{49}$

\section{El protocolo de la fiesta: la ritualización celebrativa}

Sobre el protocolo y desarrollo del festejo taurino no contamos más que con un testimonio relativo a aquello que hemos denominado festejo extraordinario. Se trata de un invaluable documento emitido por el cabildo de Santiago con motivo de la jura de Carlos III en 1760, donde se pretende protocolizar esta ceremonia real y todo lo que la rodea: «Tabla de ceremonia y etiqueta del cabildo». ${ }^{50}$ Los toros, como aspecto fundamental de este ritual, también fueron abordados para su codificación, probablemente conocida con anterioridad, aunque quizá no fijada preceptivamente. El inicio se produce con la entrada en la plaza de los alcaldes y los toreadores, estos en número de seis, «que deben ser los caballeros más distinguidos de la ciudad, a quienes gratifica el señor Corregidor». El perfil aristocrático se ratifica, pues, y también el aguinaldo. Hecha la cortesía al presidente, los alcaldes dejan sus caballos para acomodarse en sus privilegiados balcones y

46 Acuerdo, Hermandad para pedir la limosna de los pobres de la cárcel con los capítulos acordados por el M.I.S.P.G. y C.G. Ilustre Cabildo y noble vecindario, Manuel González Hidalgo, marqués de Casa Real, 12 de enero de 1764, AHN Chile, Capitanía General, 665 (microficha 07), 246r.

47 Auto, Don Juan Antonio Santa María en los autos sobre que se liberase de la contribución que tiene estipulada con la ciudad rebajándosele cincuenta pesos cada día en las corridas anuales, 16 de julio de 1773, AHN Chile, Capitanía General, 675 (microficha 02), 62r.

48 Razón de los gastos durante los cinco días de las corridas de toros, en celebración del Muy Ilustre Señor Presidente don Joaquín del Pino, 13 de noviembre de 1799, Biblioteca Nacional de Chile (BNC), antigua clasificación: tomo 214; actual: Rollo Ms. M44.

49 AHN, Chile, Capitanía General, 10, 194r-195v.

50 Cruz de Amenábar (1995, 261-262) fue la primera en publicarlo. Se encuentra en AHN, Chile, Varios, 217. 
se procede al despejo de la plaza, en dos ocasiones, la segunda por la Compañía de Dragones. Ello revela el carácter tumultuoso que debía reinar en el espacio, como demuestran numerosas fuentes gráficas en España.

Una vez despejada y concedida la llave del toril por el corregidor, los clarines indican la salida del toro, comienza la lidia. Esta se divide en dos fases y culmina con la muerte del animal, un aspecto que no era común en esta tipología de festejo. Primero intervienen los toreadores de a caballo, que se valen de rejoncillos de quebrar, y, tras sonar los clarines, los toreadores de a pie salen a poner las banderillas. En torno a la suerte de matar, no se especifica a manos de quién se produce. En cualquier caso, toreadores de a pie y de a caballo parecen compartir de forma más o menos equitativa el protagonismo. Más interesante resulta la noticia de que los seis toros de la mañana pueden «torearse por cualquiera libremente», aunque para matarlos sea necesaria licencia del corregidor. Al toreo codificado y aristocrático vespertino se contraponía aquel espontáneo y plebeyo matinal, dando cabida a las pulsiones taurómacas del pueblo que encontraba en ello una apetecida vía de escape a tantos sinsabores diarios.

La parquedad documental sobre estas fiestas en Chile impide apuntar la práctica de tales o cuales lances, aunque encontremos referencias a aquellos más habituales: garrochas, rejoncillos, banderillas... En el documento que incumbe a los gastos relativos a la entrada del presidente Del Pino en Santiago en $1799,{ }^{51}$ aparecen dos elementos relacionados con el toreo cómico: el negro y la negra, lo que demuestra la intervención del grupo étnico en lo taurino, o «el tinajón», consistente en la colocación del gran tiesto con un burlador dentro al medio de la plaza. También se dio una de las suertes de origen americano, el «monta-toro», relacionada por Byron en una corrida hacia $1744 .{ }^{52}$ En cuanto a la suerte de matar, seña y culmen del toreo dieciochesco, se practicó, pero no siempre..$^{53}$

Los organizadores de la fiesta taurina estuvieron siempre en relación con el estamento gubernamental pues, incluso con el posterior toreo-espectáculo, será el ayuntamiento quien remate en pública almoneda el derecho de explotación de la plaza, con pingües beneficios aunque fuese un «empresario» particular el encargado de la gestión. Este mismo órgano fue el

51 Véase nota 49.

52 Byron, 1901, 139.

53 Acuerdo, Hermandad para pedir la limosna..., Manuel González Hidalgo, 12 de enero de 1764, AHN Chile, Capitanía General, 665 (microficha 07), 237r. Se especifica que en una corrida a beneficio de los presos de la cárcel en 1760 se habrán «de pagar los [toros] que se desgraciaren». 
que estipuló cinco días consecutivos de toros a celebrar en dos ocasiones anuales, estas ya más ajustadas a la pertinencia de las condiciones climáticas veraniegas: diciembre y febrero. Aunque en la documentación no queda del todo claro, también el ayuntamiento parece ser el propietario del coso, pues compra al convento dominico el terreno donde se instala, llamado el basural de Santo Domingo, «a espaldas de la claustrada hacia el río». ${ }^{54} \mathrm{El}$ coso, frágilmente permanente, era el escenario que sustituía a las talanqueras colocadas en la plaza mayor, pero sin poder hacer uso ya de este ónfalos citadino. La corrida se trasladará a emplazamientos periurbanos y diversos: la Chimba, al otro lado del río, la Alameda adentro y, con más asiduidad, al dicho basural de Santo Domingo, curioso paralelismo con Sevilla, que instala su plaza en lo que fue el muladar del Baratillo. Se conserva, realizado por el maestro Juan Briceño, un plano de esta plaza de maderos, que tanto mantenimiento habría de necesitar (figura 5). En Santiago nunca llegó a

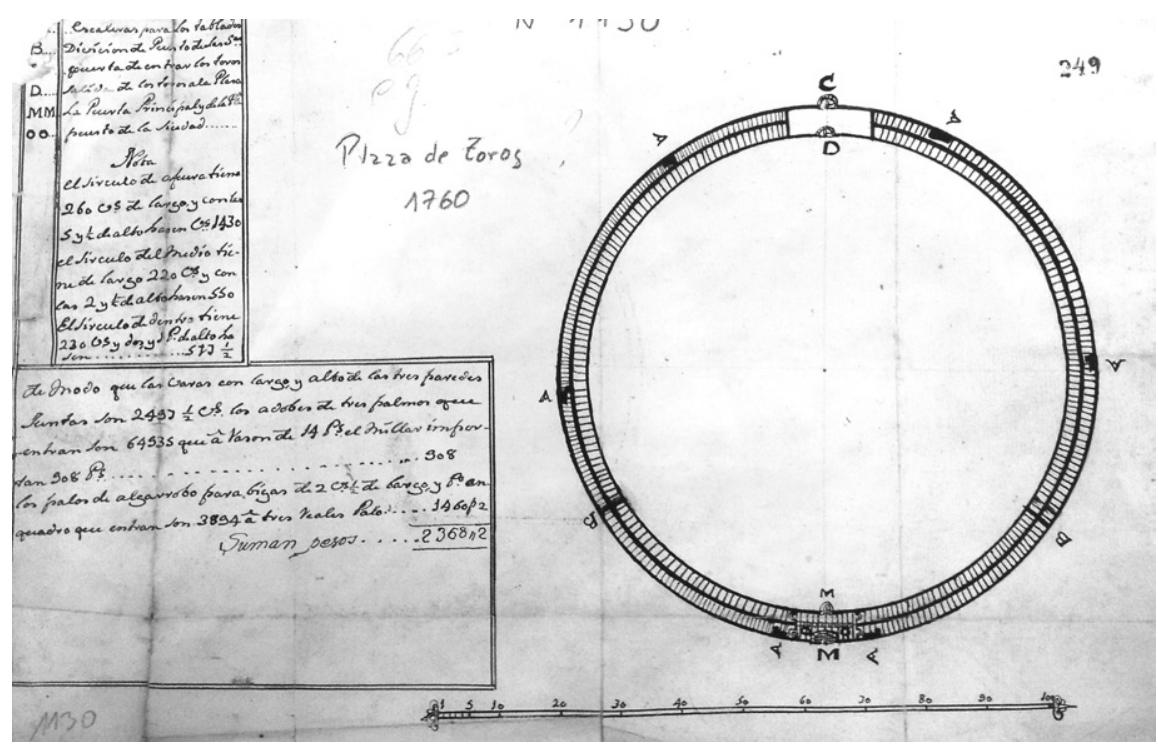

Figura 5. Dibujo con la planta de la plaza de toros de maderamen para Santiago, Maestro Juan Briceño, 1760, ANH Chile, Capitanía General (Colección de mapas, planos y dibujos), 665, 249r.

54 Expediente, Tasación del sitio nombrado El Basural que compró la ciudad al Convento de Predicadores, 1796, AHN Chile, Capitanía General, 969 (microficha 06), 68r. 
existir una plaza de cal y canto como en Buenos Aires o Montevideo, aunque en la documentación se expresa la intención de que «se vaya de año en año haciendo de firme el sitio de los toros» ${ }^{55}$.

\section{La fiesta taurina y sus implicaciones sociales}

La fiesta taurina fue utilizada como instrumento de dominación ideológica, una pedagogía para que el pueblo recibiese el mensaje de superioridad de sus señores. En los festejos extraordinarios como las juras, la plaza se transformaba en un espacio donde la nobleza renovaba ritualmente la aceptación de su superioridad. Era el escenario ideal para la demostración del estatus de cada uno. El repartimiento de balcones - por cierto, fuente de no pocos conflictos - así lo revelaba. En la «Tabla de ceremonia y etiqueta del cabildo», ya citada, se especifica el espacio concedido a cada organismo. ${ }^{56}$ Este sistema de privilegios se trasladó al toreo-espectáculo, como demuestran las quejas de los empresarios. Johnston decía en 1811 que en Santiago a las corridas iba «gente de más suposición que al teatro». ${ }^{57}$ Los tendidos eran, pues, reflejo especular de la sociedad de la época y su clasificación. No obstante, los toros fueron una fiesta integradora, donde participó toda la sociedad y, lo más importante, donde desde muy pronto se asimiló como participantes activos a todos los grupos étnicos y sociales: indios, castas, mestizos, negros... y también a las mujeres. No creemos pecar de exagerados o poco rigurosos si afirmamos que la fiesta taurina fue uno de los espacios de más igualdad fáctica del periodo virreinal.

Las corridas de toros constituían un espacio visible que escondía tras de sí las tensiones respecto al orden social urbano en la ciudad de Santiago, así como de la moralidad cristiana en una colonia remota de la monarquía católica española. Al pesquisar las noticias referidas a este evento, podemos ver cómo los principales poderes de la época — el eclesial y el secular- se involucraban en discusiones que tenían como trasfondo las oportunidades

55 Acuerdo, Hermandad para pedir la limosna..., Manuel González Hidalgo, 12 de enero de 1764, AHN Chile, Capitanía General, 665 (microficha 07), 237r. Para el estudio de la tipología de plaza de toros dirigimos a Halcón, 1990.

56 Veáse más arriba, nota 51. El repartimiento quedaba de la siguiente manera: treinta varas para la Real Audiencia y cabildo, doce para el cabildo eclesiástico, ocho para la universidad, seis para cada colegio, cuatro para cada uno de los seis tenientes; a los escribanos le correspondían los arcos bajos de la casa del cabildo y ya el resto podía venderse a particulares.

57 Johnston, 1901, 137. 
y obstáculos para formar buenos cristianos y buenos ciudadanos, respectivamente. El que sea este un espacio de tensión no significa que estos dos agentes hayan estado siempre enfrentados, sino más bien que las corridas de toros eran una excusa para proponer una determinada forma de gobernar las almas y las mentes de los pobladores de Santiago durante su historia anterior a la independencia. En estas fiestas se jugaban valores como la austeridad, la piedad, la moralidad y el orden, que en el escenario lúdico y necesario de la fiesta no siempre encontraban un campo de cultivo fértil para poder desarrollarse. En las corridas de toros ocurrían muchas cosas que atemorizaban y escandalizaban a ciertos eclesiásticos o autoridades porque el pueblo podía desbandarse. En este sentido, entonces, las fiestas en general y las de toros en particular ejercieron un importante papel en la vida urbana de los habitantes de Santiago hasta comienzos del siglo XIX.

No es raro que este entretenimiento haya tenido sus controversias en nuestro territorio. Ya el año 1567 el papa Pío V lo había prohibido para la cristiandad bajo pena de excomunión. Imbuido del espíritu contrarreformista romano de mediados del siglo XVI, el papa decidió luchar contra todos los vicios e inmoralidades y auspiciar una vida terrenal cristiana, austera y virtuosa. Dentro de las costumbres que detestaba por considerarla pagana y bárbara estaba la fiesta de los toros. En la bula prohibió los toros con castigo de excomunión inmediata y perpetua a quienes desobedecieran y a los que murieran lidiando se les negaría sepultura cristiana. ${ }^{58} \mathrm{En}$ Italia la prohibición fue acatada de forma inmediata, no así en países como España, Francia y Portugal donde la tradición de los toros estaba muy arraigada. Eran el espectáculo público más popular de España. El rey interpretó la bula a su manera, argumentando que la forma en que las corridas se llevaban a cabo en su territorio no era peligrosa, que era una forma en que sus vasallos se entretenían y que además constituían un ensayo de los ejercicios militares. ${ }^{59}$

A pesar de esta prohibición, tenemos referencia de la presencia de toros en Chile en la celebración de la llegada del gobernador Bravo de Saravia el año 1568. No había pasado ni un año de la prohibición y en Chile parecía no cumplirse esta disposición. ¿A qué se debe esto? Sencillamente a que en España, la bula nunca se hizo pública. Incluso Felipe II intentó convencer al papa de que la derogase, pero no tuvo éxito. Esperó la llegada del nuevo pontífice - Gregorio XIII- para renovar las conversaciones. Lo que obtuvo fue que la pena se levantase solamente a los laicos, quedando entonces

58 Pereira Salas, 1947, 65.

59 Villarroel, 1738, 351. 
vigente para los eclesiásticos. Además, no podían efectuarse en días festivos. Las disyuntivas que causaba la posible presencia de eclesiásticos en las corridas de toros, llevó a preguntarse si era pecado mortal o venial que los obispos asistieran. Según el padre Pedro Hurtado de Mendoza - muy escrupuloso en temas de toros- «los obispos y los eclesiásticos de grande calidad pecan mortalmente si ven los toros» ${ }^{60}$ por considerar la actividad intrínsecamente mala. Pero, como veremos más adelante, las opiniones estaban divididas entre los religiosos.

Otra referencia a la discusión respecto a los toros y el probable no acatamiento a las disposiciones religiosas de la alta jerarquía, es la que se relata en una junta del cabildo en el año 1582. Como excusa para poder celebrar libremente, se recurre a los hechos ya consumados: tanto en España como en Perú se estaban llevando a cabo, jincluso en vista y presencia de autoridades eclesiásticas e inquisidores ${ }^{161}$ Más adelante, concretamente en el papado de Clemente VIII en 1596, se derogaría la bula de Pío V. Mientras el rey y el papado discutían en Europa el destino de las corridas de toros para la cristiandad, en esta lejana colonia se discutía acerca de los detalles de su realización. Debían hacerse para cada fiesta de Santiago, San Juan y la Asunción, como constatan las actas del cabildo secular de aquella época.

Tenemos algunos vestigios de que la prohibición se conoció en Chile pero no se cumplió: uno de ellos es el hecho de que el cabildo le pide licencia al obispo para poder hacer corridas de toros el año $1579 .{ }^{62}$ También está el hecho de que el año 1582 el cabildo discute si es realmente escandaloso realizar corridas de toros. Para argumentar que no, recurren al hecho de que estas se realizan en Lima y a la necesidad que hay en Chile de llevarlas a cabo para ejercitar el arte militar.

Pereira Salas dice que la sociedad santiaguina conoció las disposiciones que hiciera el papa Pío $\mathrm{V}$ en la bula, pero se interpretó y discutió acorde a las circunstancias locales, argumentando que la situación de permanente guerra en esta parte del imperio, hacía necesario que no terminara el arte militar.

Y así como las autoridades eclesiásticas tenían sus preocupaciones, las civiles también tenían las suyas. Al comienzo era difícil organizarlas porque la Capitanía era muy pobre y se consideraba impensable matar en «un sangriento y costoso combate» a un animal que era tan caro y difícil

60 Ibidem, 352.

61 Cabildo de Santiago, 18 de julio de 1582, AHN Chile, ACS, 2..$^{\circ}$ rollo LCH 95.

62 Cabildo de Santiago, 10 de julio de 1579, AHN Chile, ACS, 1. ${ }^{\circ}$ rollo, LCH 94. 
de reproducir. ${ }^{63}$ Para las corridas mismas, el cabido debía dar disposiciones claras respecto a la organización, porque si esto no ocurría, comenzaban las irregularidades y desórdenes en el espacio público. Las barreras para contener el espectáculo en las calles aledañas a la plaza mayor debían ser firmes y estar bien construidas para evitar que los toros se desbandasen e hicieran daño a algún vecino. El que no lo hiciera según lo dispuesto, tendría pena de diez pesos. ${ }^{64}$ Había que limpiar la plaza mayor, hacer el tablado para que se sentaran los señores del cabildo y los regidores y proveer todo lo que fuera necesario para poder celebrar.

Durante el siglo XVII la ciudad de Santiago fue escenario de varias fiestas tanto civiles como religiosas. En todas ellas había corridas de toros y una preocupación explícita porque no dejaran de hacerse y se guardara su continuidad. En las actas del cabildo de la primera mitad del siglo XVII abundan las expresiones: «como suelen hacerse» o «como es costumbre», «como es uso y costumbre», «la costumbre antigua», demostrando que su permanencia era algo importante para el pueblo que necesitaba divertirse y evadirse de una vida cotidiana dura y ruda. Revisando las actas del cabildo, llama la atención que cuando hay que discutir sobre las corridas de toros, los acuerdos son siempre unánimes. Insertamos aquí una cita de uno de los acuerdos del cabildo, para dar cuenta del tono y de las preocupaciones aparejadas a las celebraciones de las fiestas:

Este día propuso el señor gobernador don Gaspar de Ahumada, corregidor de la ciudad, que a causa de la celebración de las fiestas de toros del Señor Santiago y de la venida del señor presidente de la Real Audiencia don Juan Henríquez, se realizan las corridas a partir del 22 del corriente, además de echar bando al señor corregidor y que los corregidores y alcaldes convidaran a los caballeros que iban a salir a las fiestas. Así también, se manda a convidar para que vean las fiestas, al señor presidente y oidores de la Real Audiencia y que el síndico mayordomo de la ciudad cuidara del aderezo y adorno de los asientos. ${ }^{65}$

En el cabildo se acordaba cada año quién costearía las fiestas, quién haría el toril, quién cercaría la plaza y quién adornaría los tablados. Si las autoridades civiles las auspiciaban, había entonces un importante actor de la sociedad santiaguina colonial que las veía bajo un buen concepto. Sin embargo, se insiste explícitamente en la condición de hacerlas siempre con

63 Pereira Salas, 1947, 63.

64 Ibidem, 64.

65 Cabildo de Santiago, 7 de septiembre de 1672, AHN Chile, ACS, 12. ${ }^{\circ}$ rollo, LCH 126. 
mucha decencia y con la veneración que «se debe y conviene» ${ }^{66} \mathrm{O}$ «con todo gusto», como se recomienda en otra acta edilicia. ${ }^{67}$

Pero no solamente este actor secular veía con buenos ojos las corridas de toros para las celebraciones, sino también importantes figuras representativas de los poderes eclesiásticos, como es el caso de fray Gaspar de Villarroel, quien escribe un tratado de defensa el año 1656. Este describe el barroquismo y fastuosidad que espera de una fiesta en general y de los toros en particular. Para él, las fiestas, saraos, toros y otras diversiones y ruidos que una sociedad pueda llevar acabo, son gritos a Dios para que escuche a un pueblo que está a punto de dar un estallido.

El tratado de Villarroel es muy interesante porque recoge las clásicas críticas que tradicionalmente se habían argüido contra los toros y se hace cargo de ellas. Respecto a lo que dijera el padre Hurtado de Mendoza en torno a la naturaleza intrínsecamente mala de los toros, Villarroel argumenta que el propio papa había otorgado ciertas dispensas. Si esto era así, lo malo de los toros no era intrínseco sino relativo a las personas, los lugares y las situaciones.

Contraponiéndose a lo expresado por Hurtado de Mendoza sobre la peligrosidad de la forma en que se corren en España, Villarroel cita a otra autoridad (Villalobos y la Universidad de Salamanca) diciendo que eso no es así si se hacen con moderación, se resguarda debidamente a la gente disponiendo de varias guaridas y se les corta las puntas de los cuernos al toro. Cuando ha habido muertes de toreadores ha sido porque estos han sido imprudentes o porque ha habido un accidente y no porque la actividad sea peligrosa en sí. Respecto a que no se corran toros los días de fiestas, Villarroel argumenta que eso debe interpretarse como que no se realicen en las tardes, en que son los oficios divinos, pero en las mañanas pueden correrse. A Villarroel también le importa el orden público. En su tratado releva la importancia de aquellos que hacen tablados para alquilarlos y ganar dinero con eso, así como los que alquilan sus balcones o ventanas. Con este tipo de iniciativas, los toros se pueden ver con toda seguridad y se evitan peligros. ${ }^{68}$

Entre los fieles, había quienes justificaban los toros con el argumento de que el obispo de Lima no los había prohibido para el Concilio Limense de 1682, o los que decían que los toros no hacían daño a los toreadores cuando respetaban la santidad de san Francisco Solano, «a cuyo honor se

66 Cabildo de Santiago, 19 de diciembre de 1654, AHN Chile, ACS, 9. ${ }^{\circ}$ rollo, LCH 116.

67 Cabildo de Santiago, 16 de julio de 1666, AHN Chile, ACS, 11. ${ }^{\circ}$ rollo, LCH 125.

68 Villarroel, 1738, 354-356. 
hacían las fiestas». ${ }^{69}$ Cuando en un acta del cabildo de 1604 leemos que se acuerda que se hagan las fiestas a Santiago y que «le corran toros», ${ }^{70}$ no podemos sino entender que el lenguaje discursivo es elocuente de la relación entre fiesta y devoción en aquella época. El año 1658, para los preparativos de la fiesta de Santiago, se decide que se «hagan algunas alegrías y corran toros tres días», como agradecimiento por los buenos sucesos que Dios le ha dado al ejército. ${ }^{71}$

Como una forma de entender la lealtad a la monarquía española es que se hacían fiestas con toros cada vez que había funciones reales. El año 1638 se festeja la coronación de Fernando III y en 1664 le toca a Carlos II. En ambos casos hubo varios días de cañas y toros.

A pesar de este ambiente bastante propicio para la celebración de fiestas de toros en Santiago durante el siglo XVII, hay también voces de críticas frente a los excesivos gastos en los que había que incurrir para financiar esta fiesta. Era obligación financiar los toros y todos los refrescos y comidas que se consumían durante las fiestas. El que no lo hacía debía pagar una multa, sobre todo porque implicaba un desaire a la Audiencia. ${ }^{72}$

También se ven rencillas entre los poderes religioso y civil con las corridas de toros como moneda de cambio. Si la Iglesia se sentía ofendida por alguna razón, acudía a las amenazas y los castigos para con el poder civil. Y quedarse sin toros era un castigo significativo. Un evento interesante a este respecto es el cambio de fecha en la celebración de las fiestas del apóstol Santiago con sus respectivos toros en 1631 a raíz de un conflicto con el obispo Francisco de Salcedo. ${ }^{73}$ Casi un siglo más tarde, el obispo de Santiago se niega asimismo a asistir a la fiesta de Santiago porque los miembros del cabildo no habrían asistido, por su parte, a la fiesta de san Justo y Pastor que organizara el propio obispo. ${ }^{74}$

El siglo XVIII es de grandes cambios para la actividad taurina. Vemos que el cabildo, preocupado por los daños que pueda provocar correr toros en el centro de la ciudad, recomienda ahora hacerlo «a extramuros del poblado». Entre estos, el que se comiencen a proyectar y fabricar plazas de toros. Pero en este proceso de institucionalizar la fiesta en un espacio especial y alejarla de las plazas y calles públicas, muchos eclesiásticos continuaron

69 Pereira Salas, 1947, 66.

70 Cabildo de Santiago, 23 de julio de 1604, AHN Chile, ACS, 3. ${ }^{\circ}$ rollo, LCH 110.

71 Cabildo de Santiago, 30 de agosto de 1658, AHN Chile, ACS, 10. ${ }^{\circ}$ rollo, LCH 117.

72 Pereira Salas, 1947, 69.

73 Cabildo de Santiago, 24 de julio de 1631, AHN Chile, ACS, 7. . rollo, LCH 114.

74 Cabildo de Santiago, 13 de noviembre de 1711, AHN Chile, ACS, $16 .^{\circ}$ rollo, LCH 130 
oponiéndose y poniendo obstáculos. Como ocurrió el año 1732 cuando, después del terremoto, unos capitanes tuvieron la iniciativa de organizar una corrida de toros de beneficencia en la Chimba para ayudar a reconstruir una capilla. Esta iniciativa no fue del gusto del arzobispo Pedro de Azúa, quien instigó a las autoridades para impedirlo. Para él, era esto algo inadecuado en días de calamidades.

Más rotunda aun fue la proclamación de Azúa de un sínodo diocesano el año 1744, donde se quejaba de que las fiestas se estaban profanando y que se habían convertido en verdaderos espectáculos teatrales y se había perdido por completo el respeto y la devoción. Se quejaba asimismo de que los dineros se estaban malgastando porque en estas fiestas públicas se llegaba a todo tipo de abusos entre hombres y mujeres, que terminan estando muy cerca. El documento se dirigía a los sacerdotes para que excomulgaran a las cofradías que organizaran comedias o toros. Azúa reconocía que lidiar toros no era intrínsecamente malo, pero no era cosa para religiosos ni para días festivos, por considerarlo inoportuno. ${ }^{75}$

Algunos años antes, el cabildo catedralicio había prohibido las corridas de toros por considerarlas nocivas para las almas de sus feligreses. Se acuerda que el cabildo eclesiástico escribiría una carta a los señores de la Real Audiencia explicando el motivo de la prohibición. ${ }^{76}$ Por su parte, la autoridad civil manifestaba su preocupación por los desórdenes de los ciudadanos involucrados en las fiestas de toros. En las ventas de bebidas y comidas expendidas durante esos días, hombres y mujeres en concurso entran en pleitos, embriagueces y otros excesos criminales. Se dispone que en esos casos deberán evacuarse las ventas del interior y el exterior de la plaza de toros. A quien no obedeciera, se le darían penas según su condición social y se quitarían los permisos para expender licores. También hay orden de mantener el recinto iluminado con faroles por dentro y por fuera, también con pena de multas en caso de incumplimiento. ${ }^{77}$

Otro vicio que se quiere evitar en los días de corridas de toros es el de las rifas y las ruedas de fortuna. Incluso se habla de no tener ni retretes para que no haya encuentros ilícitos entre hombres y mujeres

75 Pereira Salas, 1947, 71.

76 Cabildo de la catedral de Santiago, 20 de febrero de 1702, Archivo Arzobispal de Santiago de Chile, Actas del cabildo de la catedral de Santiago, libro II, 46v-47r. Confirma la prohibición de las corridas de toros.

77 Expediente, Tasación del sitio nombrado El Basural que compró la ciudad al Convento de Predicadores, 1796, AHN Chile, Capitanía General, 969 (microficha 06), 198r. 
No obstante, las lidias de toros eran, como hemos estado revisando, un espacio para discutir problemas más generales. Pareciera que en Chile las menguadas dimensiones de la fiesta no daban para hablar tampoco de grandes desórdenes, como sí ocurría, en cambio, en lugares como Lima y México. Podemos agregar que las finanzas de esta colonia distaban mucho de la riqueza que ostentaban otras ciudades del imperio español. Todo esto incidía en la magnitud de las fiestas, que eran más esporádicas y menos lustrosas que las de otras localidades. A pesar de esto, las gentes se quedaban hablando durante meses y años, al punto de que surgiría la expresión «habrá toros» para referirse a varios días seguidos de fiestas.

Recibido el 27 de agosto de 2015 Aceptado el 1 de diciembre de 2015

\section{Referencias bibliográficas}

Alemparte Robles, Julio, El cabildo en Chile colonial. (Orígenes municipales de las repúblicas hispanoamericanas), Universidad de Chile, 1940.

Alfonso Mola, Marina y Martínez Shaw, Carlos, «Fiestas reales y toros en el Quito del siglo XVIII», en García-Baquero, Antonio y Romero de Solís, Pedro (eds.). Fiestas de toros y sociedad. Actas del Congreso Internacional 2001, Sevilla, Universidad de Sevilla y Fundación de Estudios Taurinos, 2003, 123-138.

Arzáns de Orsúa y Vela, Bartolomé, Historia de la villa imperial de Potosí, La Paz, Ministerio de Educación y Cultura, 1970.

Barros Arana, Diego, Historia General de Chile, Santiago de Chile, Editorial Universitaria, Centro de Investigaciones Diego Barros Arana, 2000, t. I.

Byron, John, Relato del honorable John Byron (comodoro de la última espedición alrededor del mundo) que contiene una esposición de las grandes penurias sufridas por el $i$ sus compañeros en la costa de la Patagonia desde el año 1740 [...], Santiago de Chile, Imprenta Cervantes, 1901.

Campos y Fernández de Sevilla, F. Javier (dir.), La Inmaculada Concepción en España: religiosidad, historia y arte. Actas del Simposium, San Lorenzo del Escorial (Madrid), R.C.U. Escorial-M. ${ }^{a}$ Cristina, 2005.

Castillo Martos, Manuel, «Toros en el altiplano andino (1550-1560). Una aproximación a su historia», en García-Baquero, A. y Romero de Solís, P. (eds.), Fiestas de toros y sociedad: Actas del Congreso Internacional 2001, Sevilla, Universidad de Sevilla y Fundación de Estudios Taurinos, 2003, 211-234.

Chacama Rodríguez, Juan, «Imágenes y palabras, dos textos para un discurso: la prédica pastoral en los Andes coloniales. Doctrina de Codpa (Altos de Arica), siglo XVIII», Diálogo andino, 33, Arica, 2009, 7-27. 
Chiappa, Víctor M., Noticias bibliográficas sobre la Colección de Historiadores de Chile y documentos relativos a la historia nacional, Santiago de Chile, Imprenta de Enrique Blanchard-Chessi, 1905.

Cossío, José María de, Los toros: tratado técnico e histórico, Madrid, EspasaCalpe, 1951, tomo VI.

Cruz de Amenábar, Isabel, La fiesta: metamorfosis de lo cotidiano, Santiago de Chile, Pontificia Universidad Católica de Chile, 1995.

De María y Campos, Armando, Breve historia del teatro en Chile y de su vida taurómaca, México, Cepsa, 1940.

Fournier, Dominique, «Corrida, charreada et jaripeo. Identité taurine mexicaine et métissage culturel», en Molinié-Bertrand, A.; Duviols, J. P. y Guillaume-Alonso, A., Des taureaux et des hommes: tauromachie et société dans le monde ibérique et ibero-américain: actes du colloque international, Paris, Presses de l'Université Paris-Sorbonne, 1999, 187-199.

García-Baquero González, Antonio, Razón de la tauromaquia, obra taurina completa, Sevilla, Fundación Real Maestranza de Caballería de Sevilla-Fundación de Estudios Taurinos, Universidad de Sevilla, 2008.

Garcilaso de la Vega, El Inca, Comentarios Reales de los Incas [1609], ed. de Aurelio Miró Quesada, Caracas, Biblioteca Ayacucho, 1976, tomo II.

Guarda, Gabriel, «"El triunfo del deseo”, auto de Martínez de Bernabé en la jura de Carlos III en Valdivia, 1760», Anales de la Universidad de Chile, 5. a serie, 5, Santiago de Chile, 1984, 241-262.

Guillaume-Alonso, Araceli, La tauromaquia y su génesis: ritos, juegos y espectáculos taurinos en España durante los siglos XVI y XVII, Bilbao, Laga, 1994.

Halcón, Fátima, La plaza de toros de la Real Maestranza de Caballería de Sevilla, Madrid, El Viso, 1990.

Iwasaki Cauti, Fernando, «Toros y sociedad en Lima colonial», Anuario de Estudios Americanos, 49, Sevilla, 1992, 311-333.

Johnston, Samuel B., Cartas escritas durante una residencia de tres años en Chile, en las que se cuentan los hechos más culminantes de las luchas de la revolución en aquel país, traducción J. T. Medina, Santiago-Valparaíso, Imprenta y Litografía Barcelona, 1917.

López Izquierdo, Francisco, Los toros del Nuevo Mundo (1492-1992), Madrid, Espasa Calpe, 1992.

Maudet, Jean-Baptiste, Terres de taureaux: les jeux taurins de l'Europe á l'Amérique, Madrid, Casa de Velázquez, 2010.

Medina, José Toribio, Actas del Cabildo de Santiago, Colección de Historiadores de Chile y documentos relativos a la historia nacional, XIX, Santiago de Chile, Imprenta Elzeviriana, 1899, t. IV.

Medina, José Toribio, Cosas de la colonia: apuntes para la crónica del siglo XVIII en Chile, Santiago, Fondo histórico y bibliográfico José Toribio Medina, 1952. 
Molina, Juan Ignacio, Compendio de la historia geográfica, natural y civil del reyno de Chile, Primera parte, Madrid, Antonio de Sancha, 1788.

Molinié-Bertrand, Annie; Duviols, Jean-Paul y Guillaume-Alonso, Araceli, Des taureaux et des hommes: tauromachie et société dans le monde ibérique et ibero-américain: actes du colloque international, París, Presses de l'Université Paris-Sorbonne, 1999.

Molinié, Antoinette, «El toro y el cóndor en lidia: una corrida en los Andes peruanos», en García-Baquero, A. y Romero de Solís, P. (eds.), Fiestas de toros y sociedad: Actas del Congreso Internacional 2001, Sevilla, Universidad de Sevilla y Fundación Estudios Taurinos, 2003, 495-514.

Olivares, Miguel de, Historia militar, civil y sagrada de lo acaecido en la conquista y pacificación del reino de Chile [1758], Colección de historiadores de Chile y documentos relativos a la historia nacional, IV, Santiago, Imprenta del Ferrocarril, 1864.

Ovalle, Alonso de, Histórica relación del reino de Chile [1646], edición de Walter Hanisch, Santiago de Chile, Editorial Universitaria, 1974.

Pereira Salas, Eugenio, Juegos y alegrías coloniales, Santiago de Chile, Zig-Zag, 1947.

Primer Sínodo Diocesana [Concepción de Chile, 1744], Santiago, Imprenta del Independiente, 1867. (Edición de Santiago-Otero, Horacio y García y García, Antonio (dirs.), Sínodo de Concepción (Chile) 1744, Madrid-Salamanca, Instituto Francisco Suárez del CSIC, Instituto de Historia de la Teología España de la UPS, 1984).

Rodríguez, Pablo, «La fiesta de toros en Colombia. Siglos XVI-XIX», en Molinié-Bertrand, A.; Duviols, J.P. y Guillaume-Alonso, A., Des taureaux et des hommes: tauromachie et société dans le monde ibérique et ibero-américain: actes du colloque international, París, Presses de l'Université Paris-Sorbonne, 1999, 165-174.

Romero de Solís, Pedro, «La "Tauromaquia” de Goya y la invención de la corrida moderna», Revista de Estudios Taurinos, 2, Sevilla, 1995, 149-181.

Valenzuela Márquez, Jaime, «Poder y pirotecnia, artesanos y mapuches: apogeo barroco de las proclamaciones reales en Santiago de Chile, 1760-1789», Colonial Latin American Historical Review, 14-1, 2005, 49-78.

Valenzuela Márquez, Jaime, Fiesta, rito y política. Del Chile borbónico al republicano, Santiago de Chile, Centro de Investigaciones Diego Barros Arana y DIBAM, 2014.

Villarroel, Fray Gaspar de, Govierno eclesiástico-pacífico y unión de los dos cuchillos pontifico y regio, Madrid, Antonio Marín, 1738. 